\title{
Current Knowledge on Source and Synthesis of Conjugated Linoleic Acid (CLA): A Review
}

\author{
Prem Kumar J and Ranganathan TV* \\ Department of Food Processing and Engineering, Karunya University, India
}

Submission: September 18, 2017; Published: November 14, 2017

*Corresponding author: Ranganathan TV, Professor and Program Co-ordinator, Department of Food Processing and Engineering, School of Agriculture and Biosciences, Karunya University, Coimbatore-641114, Tamilnadu, India, Email: srivarahe@gmail.com

\begin{abstract}
Dietary fatty acids are highly recognized as an important biologic controller and having potential to provide number of health benefits. Conjugated linoleic acid is an important conjugated fatty acid with a mixture of positional and geometric isomers of linoleic acid (C18:2, n-6). In the last three decades, this particular type of PUFA has gained significant attention for their biologically active properties and health effects. CLA can be synthesized endogenously in tissues and partial bio hydrogenation of unsaturated fatty acids in rumen stomach. Also, it can be synthesized by using microbial strains like Lactobacillus spp and Butyrivibrio fibrislovens but the amount of yield obtained is not satisfactory. Application of homogenous and heterogeneous catalysts and photoisomerization methods increased the conversion of linoleic acid to CLA. In 2008, CLA got generally recognized as safe (GRAS) status by FDA, which increased the consumption of CLA and used as a nutraceutical in dietary supplements/foods. With the increasing market demand, the research should focus in developing innovative synthesis methods with enhanced productivity of specific CLA isomers. The main scope of this review is to outline the current knowledge on different types of synthesis of CLA isomers and sources rich in CLA.
\end{abstract}

Keywords: Conjugated linoleic acid; Sources; Biosynthesis; Catalysts; Enzymes

\section{Introduction}

Lipids may be bounded as "fatty acids, their derivatives, and substances connected biosynthetically or functionally to these compounds" [1]. It mainly consists of triacylglycerol (TAG's), which are molecules composed of three fatty acids and glycerol (phosphatidylcholine and cholesterol also included) [2] and generally found in the tissues of microorganisms, plants, animals and insects [3-6]. TAG's and fatty acids accelerated the absorption of other fat-soluble components such as vitamins. As well with proteins, carbohydrates, and alcohol, fats are a major source of energy for the body and also serve many essential functions (e.g. Structural components of cell membrane, regulators of enzyme activities (e.g. protein myristoylation), precursors for bioactive molecules, and regulation of gene expression). Fatty acids can be categorized according to their number of double bonds. Saturated fatty acids (SFA) have no double bonds, while monounsaturated fatty acids (MUFA) have one double bond and polyunsaturated fatty acids (PUFA) have two or more double bonds [2]. PUFA have 2 to 6 double bonds and PUFA having 20 or more carbon atoms are usually termed as LCPUFA both are essential for physiological activities of the organism.

In specific, polyunsaturated fatty acids (PUFA's), such as linoleic acid (18:2, n-6), $\alpha$-linolenic acid (LNA, 18:3, n-3), arachidonic acid (ARA, 20:4, n-6), Eicosapentenoic acid (EPA, 20:5, n-3) and docosahexaenoic acid (DHA, 22:6, n-3) are termed as conjugated fatty acids (CFA's). Conjugated fatty acids are the positional and geometric isomers of unsaturated fatty acids, containing one or more non-methylene contributed double bonds in either cist or trans conformation (Figure 1).

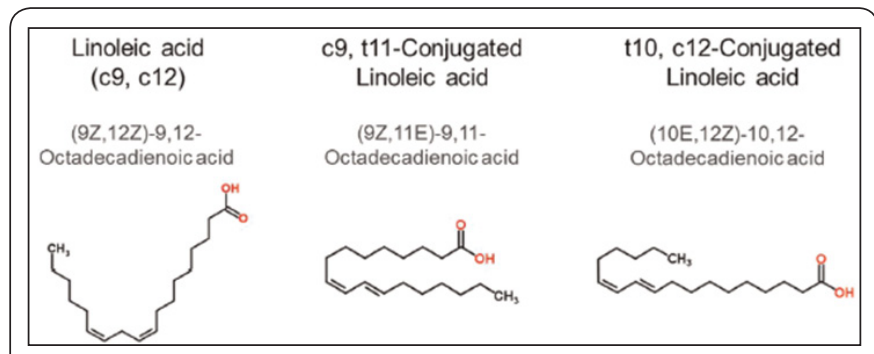

Figure 1: Structure of linoleic acid, cis-9 trans trans-11 CLA isomer and trans-10 cis-12 CLA isomer (Adapted from Viladomiu et al. [9]).

The first bioactivity of conjugated fatty acid was reported in 1979, an anti-carcinogenic component in ground beef extract which reduced the tumors in the mice which was strongly exposed to a carcinogen. This unique anti-carcinogen was not doped-out until almost a decade later, in 1987, Michael Pariza, the scientist who ascertained conjugated linoleic acid (CLA), later commented that few ant carcinogens, and probably no other known fatty acids, are as effective as CLA in preventing carcinogenesis [7,8]. Since then, CLA isomers have been 
connected with a range of bioactivities including anti-microbial, anti-diabetogenic, anti-atherosclerotic, anti-obesogenic, along with enhanced bone formation, increased immune functions and improved body fat metabolism [9-15].

CLA can be found in dairy foods, meat from ruminants and some vegetable oils. Naturally CLA will occur in tissues by endogenous conversion of trans-vaccenic acid and partial bio hydrogenation of unsaturated fatty acid in rumen stomach. Microbial synthesis using bacterial strains also possible but the rate of conversion and yield is not satisfactory. Chemical synthesis using metal catalysts and photoisomerization methods provided better conversion rate and yield. With GRAS status by FDA in 2008 and containing number of health giving properties, CLA can be used in certain food categories like yogurt, meal replacement shakes, fluid milk, fruit juices, nutritional bars and soy milk. The primary focus of this paper is to review the current knowledge about the synthesis of CLA isomers and sources rich in CLA.

\section{Sources of CLA}

Food products obtained from ruminant animals are the principal resources of CLA in the human diet. In dairy products, CLA content ranges from 2.9-8.92mg CLA/g fat, of which the 7393 percent of total CLA is c-9, t-11 CLA isomer [16]. The CLA content in cheeses typically ranges from 3.59 to $7.96 \mathrm{mg}$ CLA/g fat. Cheeses like Blue, brie, edam and Swiss contain higher CLA content than other cheeses particularly in sharp cheddar cheese the concentration of CLA is higher than medium cheddar cheese $[17,18]$.

In cultured dairy products, CLA content ranges from 3.82 to $4.66 \mathrm{mg}$ CLA/g fat. CLA content of cow's milk typically ranges from 3.38 to $6.39 \mathrm{mg}$ CLA/g fat; whereas, significant variation of CLA content of cow's milk products occurs [19]. These variations mainly attributed to individuals and herds and between seasons. Animals grazing in sunlight enhance the CLA concentration in milk. Anyhow, human milk always tends to contain low level of CLA than cow milk ranges from $0.37 \%$ to $0.75 \%$ of fat [20]. The major CLA isomer in bovine [21] and human [20] milk was reported to be the $\mathrm{c}-9, \mathrm{t}-11$ CLA isomer.

Human diet contains meat and meat products which is obtained from variety of animal species (Table 1). Particularly meat from grass-fed animals has greater concentration of CLA than meat from non grass-fed animals. Beef contains low level of CLA $(1.2-10.0 \mathrm{mg} / \mathrm{g}$ lipid) than lamb $(4.3-19.0 \mathrm{mg} / \mathrm{g}$ lipid) and turkey (2-2.5mg/g lipid). As well as meat from poultry, pork and horse meat shown only $1 \mathrm{mg} / \mathrm{g}$ lipid [22,23]. CLA level in meat that is less common in human diet like meat from elk (1.3-2.1mg CLA per gram fatty acid methyl ester (FAME)), water buffalo (1.83mg/g fatty acids), zebu-type cattle $(1.47 \mathrm{mg} / \mathrm{g}$ fatty acids) and bison (2.9-4.8mg/g FAME). Adipose tissue of kangaroos contains higher CLA concentration $(38 \mathrm{mg} / \mathrm{g}$ fatty acids) than all animals [24].
Table 1: Range of CLA content in meat products (in $\mathrm{mg} / \mathrm{g}$ FAME) $[22,23]$.

\begin{tabular}{|c|c|}
\hline Meat Product & CLA Content \\
\hline (Mg /G Fame) & \\
\hline Salami & 4.2 \\
\hline Knackwurst & 3.7 \\
\hline Black Pudding & 3.0 \\
\hline Mortadella & 2.9 \\
\hline Wiener & $1.5 / 3.6$ \\
\hline Liver Sausage & 3.3 \\
\hline Cooked Ham & 2.7 \\
\hline Beef Frank & 3.3 \\
\hline Turkey Frank & 1.6 \\
\hline Beef Smoked Sausage & 3.8 \\
\hline Smoked Bacon & $0.8-2.6$ \\
\hline Smoked Bratwurst & 2.4 \\
\hline Smoked German Sausage & 4.4 \\
\hline Smoked Ham & 2.9 \\
\hline Smoked Turkey & 2.4 \\
\hline Minced Meat & 3.5 \\
\hline Corned Beef & 6.6 \\
\hline Potted Meat & 3.0 \\
\hline
\end{tabular}

Final CLA content may vary in foods. Standard and comparable levels of CLA in a variety of foods are outlined in the following Table 2. Concentrations are found to be higher in food obtained from beef, lamb and dairy products than seafood, pork, poultry and vegetable oils. Current measures of usual or actual dietary intakes of CLA are strictly limited. Reports based on intake data from USDA's Continuing Survey of Food Intake of Individuals (CSFII 1994-1996) indicate that beef users consume $221 \mathrm{mg}$ of CLA/day; while non-beef users consume $102 \mathrm{mg} /$ day. Studies have pointed that high levels of CLA in the diet may strictly prevent many life-style associated diseases.

Table 2: CLA content in uncooked foods [18,22].

\begin{tabular}{|c|c|c|}
\hline Food & $\begin{array}{c}\text { Total CLA (Mg/G } \\
\text { Fat) }\end{array}$ & C9, T11-Isomer (\%) \\
\hline \multicolumn{3}{|c|}{ Meat } \\
\hline Fresh ground beef & 4.3 & 85 \\
\hline Beef round & 2.9 & 79 \\
\hline Beef frank & 3.3 & 83 \\
\hline Beef smoked sausage & 3.8 & 84 \\
\hline Veal & 2.7 & 84 \\
\hline Lamb & 5.6 & 92 \\
\hline Pork & 0.6 & 82 \\
\hline \multicolumn{2}{|c|}{ Poultry } \\
\hline Chicken & 0.9 & 84 \\
\hline Fresh ground turkey & 2.5 & 76 \\
\hline
\end{tabular}




\begin{tabular}{|c|c|c|}
\hline \multicolumn{3}{|c|}{ Seafood } \\
\hline Salmon & 0.3 & n.d \\
\hline Lake trout & 0.5 & n.d \\
\hline Shrimp & 0.6 & n.d \\
\hline \multicolumn{3}{|c|}{ Dairy Products } \\
\hline Homogenized milk & 5.5 & 92 \\
\hline Butter & 4.7 & 88 \\
\hline Sour cream & 4.6 & 90 \\
\hline Plain yogurt & 4.8 & 84 \\
\hline Ice cream & 3.6 & 86 \\
\hline $\begin{array}{l}\text { Sharp cheddar } \\
\text { cheese }\end{array}$ & 3.6 & 93 \\
\hline Mozzarella cheese & 4.9 & 95 \\
\hline Colby cheese & 6.1 & 92 \\
\hline Cottage cheese & 4.5 & 83 \\
\hline Reduced fat swiss & 6.7 & 90 \\
\hline Am.processed cheese & 5 & 93 \\
\hline Cheez.whiz & 5 & 92 \\
\hline \multicolumn{3}{|c|}{ Vegetable Oils } \\
\hline Safflower & 0.7 & 44 \\
\hline Sunflower & 0.4 & 38 \\
\hline Canola & 0.5 & 44 \\
\hline Corn & 0.2 & 39 \\
\hline
\end{tabular}

\section{Synthesis of conjugated linoleic acid isomers}

The two conjugated lienoic isomers cis-9, trans-11 and trans-10, cis-12 is known to contain number of biological activities. In last three decades, research on CLA has increased, particularly in food science and medicine which was believed that some specific isomers of CLA have important bioactive properties as authenticated in different experimental designs with mice, rats or pigs [25]. Considering this, many researchers have tried to scale-up the production of CLA $[26,27]$. CLA can be synthesized naturally by biohydrogenation of PUFA in the rumen or microbial synthesis by use of bacterial enzymes/anaerobic bacterium and other bacterial strains or chemical synthesis which is widely employed in industries for bulk production of CLA.

Biosynthesis of CLA: Naturally CLA synthesizes endogenously in tissues/bacterial isomeriation or/and partial biohydrogenation of PUFA's from diet in the rumen adipose tissue and mammary gland [28]. In rumen, the dietary material enters a large fermentation vat; lipids in the diet are altered by microbial population present in the rumen stomach which differentiates the fatty acid profile of lipids in the diet (mostly USFA) and lipids leaving the rumen (mostly SFA) [29]. Microbes present in the rumen would transform lipids entering the rumen via two major processes called biolysis and bio hydrogenation.

Biolysis is the process of breakdown of ester linkages that connects fatty acids. The microbial lipases hydrolyze the ester linkages in complex lipids, causing the release of fatty acids [30]. After biolysis, microbes in rumen will initiate the biohydrogenation of USFA's. Here the conversion of USFA to SFA via isomeriation to trans fatty acid intermediates, followed by hydrogenation of the double bonds [31]. The amount of fat delivered in the rumen [32] and luminal pH [33] are always considered an important factor for enhanced rate of biolysis and biohydrogenation reaction.

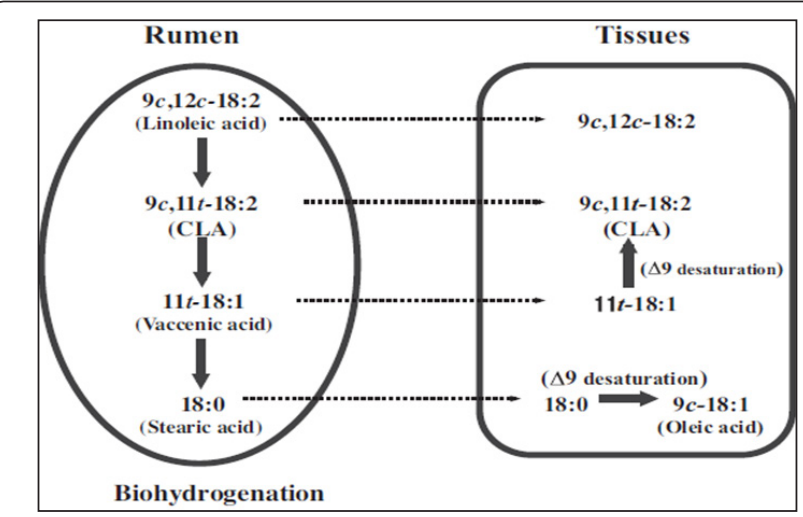

Figure 2: Renowned pathway of biohydrogenation of linoleic acid in rumen (Adapted from Koba \& Yanagita [18]).

Lipid metabolism of luminal micro-organisms directly delivers CLA or important intermediate precursors of CLA on the way to the end product static acid. For instance, the renowned pathway of linoleic acid generates $c 9, \mathrm{t} 11-18: 2$ by isomeriation and t11-18:1 (trans-vaccenic acid) by further hydrogenation as intermediates. In general, a micro-organism does not cover the entire metabolism from the initial PUFA to the end product static acid but only part of it (Figure 2). Bacterial strain like, Butyrivibrio fibrisolvens release the enzymes linoleate isomerase and CLA reductase which isomerizes is double bonds of PUFA to form conjugated $\mathrm{c} / \mathrm{t}$ double bonds and to hydrogenate these conjugated fatty acids. This process generates trans-vaccenic acid (t11-18:1) which is further hydrogenated to produce end product static acid (18:0) by other luminal bacteria [31]. PUFA like $\alpha$-linolenic acid, the main sequence leads to conversion of trans-vaccenic to static acid with intermediates other than CLA $[28,31,34]$.

Luminal $\mathrm{pH}$ acts an important parameter in isomeriation and biohydrogenation reaction [35]. In rumen, low $\mathrm{pH}$ alters the bacterial population [36] which affects the pattern of fermentation end products [37]. Griinari \& Bauman [28] reported that the decreased rumen $\mathrm{pH}$ produce t10-18:1 instead of transvaccenic acid which generate t10, c12-18:2 as an intermediate product. Whereas, the pathways would not be same for all CLA isomers and other trans octadecenoic acids found.

CLA isomers were synthesized endogenously by $\Delta 9$-desaturase, which denaturants transvaccenic acid to $\mathrm{c} 9, \mathrm{t} 11$ 18:2 [37-39]. Endogenous synthesis is the major source of c9, t11-18:2 in the milk fat which represents $78 \%$ and $64 \%$ of the total $[28,38]$. Desideration of vaccenic acid is the main source 
of CLA in the muscle lipids based on the high correlations between CLA and trans-vaccenic acid [40]. Other CLA isomers commonly derive from other trans-18:1isomers by the action of $\Delta$ 9-desaturase [28].

Whereas, endogenous synthesis was noticed in both the ruminants and non-ruminants [41-45]. The accessibility of trans-vaccenic acid is more in ruminants due to luminal bio hydrogenation [35]. As well as endogenous synthesis transvaccenic acid was documented in humans but the predominant source of CLA comes from the dietary CLA intake with meat and meat products as well as milk and dairy products [45-47].

Microbial synthesis of CLA: Biosynthesis methods have been employed to prepare a number of conjugated dynes. Researchers started synthesis of CLA isomers using bacterial enzymes from the date of discovery of bacteria which is present in the stomachs of ruminant would convert dietary unsaturated fatty acids present in the plant food sources into conjugated isomers. For example, the enzyme linoleate isomerase, isolated from the rumen anaerobic bacterium Butyrivibrio fibrisolvens, which isomerizes linoleic acid to mainly cis-9, trans-11 octadecenoic acid (also termed as rumenic acid) (US patent $6479683,2002)$.

Lactobacillus delbrueckii ssp bulgaricus and L. acidophilus were tested for CLA production which was immobilized with chitosan and polyacrylamide with different $\mathrm{pH}$. Chitosan ( $\mathrm{pH}: 8)$ and polyacrylamide (pH:7) immobilized with Lactobacillus delbrueckii ssp and L. bulgaricus has shown more CLA. Increase in cell count indicates the higher CLA production [48]. Oat lipids were used for microbial isomeriation of CLA using Propionibacterium freudnreichi ssp shermanii. The hydrolyzed oat lipids were prepared in aqueous slurries by endogenous oat lipase. The slurry congaing free LA was used as s substrate for isomeriation reaction. Nearly $80 \%$ of total CLA (c-9, t-11) formed [49].

CLA was synthesized from different forms of ricinoleic acid and castor oil with and without lipase (Lipase. M "Amano"10) using washed cells of Lactobacillus plant arum AKU 1009a as catalyst. After centrifugation, these washed cells were cultivated in MRS media containing $0.6 \mathrm{~g} / \mathrm{l} \alpha$-linolenic acid. Substrates with different concentration of $4.0 \mathrm{mg} / \mathrm{ml}$ in form of free ricinoleic acid, ricinoleic acid in methyl ester form ricinoleic acid in methyl ester form with lipase, castor oil and castor oil with lipase. Substrate with free form of ricinoleic acid and castor oil with lipase produced maximum of $1.65 \mathrm{mg} / \mathrm{ml}$ and $1.4 \mathrm{mg} / \mathrm{ml}$ of CLA compared to other forms of substrates [50].

Concentrated LA and CLA (75\%, c9, t11) solutions (0.1g/ $\mathrm{ml}$ of water with $20 \% \mathrm{BSA}$ ) added to cultures of Butyrivibrio fibriosolvens A38 which was grown at $39{ }^{\circ} \mathrm{C}$ in basal medium under oxygen free CO2. These cultures were harvested by centrifugation and cell pellets were prepared an aerobically or aerobically. Cell suspensions were incubated aerobically and an aerobically, aerobic suspensions showed higher levels of CLA compared to anaerobic suspension [51].

Bacterial strain Lactobacillus acidophilus 1.1854 were tested for CLA production using alfalfa seed oil containing linoleic acid about $40 \%$ as substrate. Under optimal condition, 50\% of conversion of LA to CLA was observed, which indicates the presence of linoleic acid isomerase activity in the culture [52]. Six strains of Lactobacillus species (Lactobacillus acidophilus L11, L12, L14, L15, Lactobacillus fermentum and Lactobacillus router) grown in MRS broth without linoleic acid at $37^{\circ} \mathrm{C}$ with varying incubation time (3-42hrs). Among different strains of Lactobacillus, L11 produced highest enzymatic activity than other strains [53]. Lactobacillus router 55739 in MRS broth with and without linoleic acid $(0.2 \%)$ were harvested and washed. The washed cells were added to buffer containing linoleic acid and without linoleic acid. The cells which have been grown without LA transformed more LA into CLA (c-9, t11) than cells grown with LA [54].

Chemical synthesis of CLA: The aim of chemical synthesis is to produce a fully characterized CLA composition with maximal biological activity. Some commercial preparations of CLA hold additional isomers with conjugated double bonds at the 8,10 or 11, 13 positions [55]. Laboratory method of preparation of CLA consisting mainly of cis-9, trans-11 and trans-10, cis-12 isomers. (E.g. CLA prepared for experimental purposes contains c-9, t-11 (40.8-41.1\%), t-10, c-12 (43.5-44.9\%) and t-9, t-11/t-10, t-12 (4.6-10\%) isomers [22,56,57].

Alkali isomeriation method is widely used for producing CLA isomers chemically. In this method, homogeneous and heterogeneous catalysts were used. The main drawback of alkali isomeriation of linoleic acid is the use of huge amount of strong basic potassium hydroxide or sodium meth oxide [58]. Homogenous catalysts are tries (triphenylphosphine) chlororhodium and arene chromiumcarbonyl complexes [59], which enable lower reaction temperatures than $180-200{ }^{\circ} \mathrm{C}$ necessary for non-catalyzed systems. Homogenous catalysts are soluble homogenous metal complexes which are not ecofriendly and difficult to separate but heterogeneous catalysts are easy to separate and reuse. Hence, heterogeneous catalysts are advised for isomeriation reaction of linoleic acid. Solvents containing hydrogen transfer agents are used for isomeriation of methyl linoleate and rhodium and ruthenium supported with carbon was used as catalysts between 200 and $270{ }^{\circ} \mathrm{C}$ in different solvents $[60,61]$.

In isomeriation, the activities and selectivity's are reported to be dependent on the solvent used. For better selectivity, always non-polar solvents were used and high solvent/reactant ratio is preferred to avoid polymerization reaction. In case of hydrogenation, highly protect solvents such as methanol and isopropyl alcohol were used, which exhibits high activity and selectivity [62]. In CLA synthesis, isomeriation and hydrogenation are two competing identical reactions. Isomeriation occurs in 
the absence of hydrogen preadsorption with the solvent being a hydrogen transfer agent, but the conjugation reaction is enhanced by catalyst reactivation under hydrogen. The catalyst holds chemisorbed hydrogen on the surface does not only increase the total conversion, but also increases the hydrogenation reaction of linoleic acid and CLA [63].

Metals like $\mathrm{Ni}, \mathrm{Pt}, \mathrm{Pd}, \mathrm{Rh}, \mathrm{Ru}$ and Ir and other transition elements like $\mathrm{Cr}, \mathrm{Mo}, \mathrm{W}, \mathrm{Cu}$ and $\mathrm{Zn}$ were frequently used catalysts for hydrogenation [64]. The effect of $\mathrm{RuCl}_{2}\left(\mathrm{PPh}_{3}\right)_{3}$ on isomeriation of industrial oils like rape seed oil, soybean oil and linoleic acid was investigated. The highest yields (88-91\%) of conjugated isomers in the oils were obtained in the reactions carried out for $0.75-1.5 \mathrm{hrs}$ within the temperature range of 212$226{ }^{\circ} \mathrm{C}$ and with concentration of 0.03 to $0.110 \mathrm{wt} \%$ [65].

Larock et al. [66] employed $0.1 \mathrm{~mol} \% \quad\left[\mathrm{RhCl}\left(\mathrm{C}_{8} \mathrm{H}_{14}\right)_{2}\right]_{2}$, $0.25 \mathrm{~mol} \% \quad \mathrm{PtCl}_{2}\left(\mathrm{PPh}_{3}\right)_{2}$ or $0.5 \mathrm{~mol} \%$ RuHCl(CO) $\left(\mathrm{PPh}_{3}\right)_{3}$ to isomerizes the soybean oil to conjugated soybean oil under mild reaction condition. The $\left[\mathrm{RhCl}\left(\mathrm{C}_{8} \mathrm{H}_{14}\right)_{2}\right]_{2}$ catalyst provided high yield of conjugated linoleic acid without any hydrogenated product. Heterogeneous catalyzed conjugation reaction of linoleic acid over metals $\mathrm{Ru}, \mathrm{Ni}, \mathrm{Pd}, \mathrm{Pt}, \mathrm{Rh}, \mathrm{Ir}$, Os and $\mathrm{Pt}-\mathrm{Rh}$ supported by carbon, $\mathrm{Al}_{2} \mathrm{O}_{3}, \mathrm{SiO}_{2} \mathrm{Al}_{2} \mathrm{O}_{3}, \mathrm{H}-\mathrm{MCM}-41, \mathrm{MCM}-22$, $\mathrm{H}-\mathrm{Y}$ and $\mathrm{H}-\mathrm{\beta}$ (metal modified acidic zeolite) at mild reaction condition in batch wise manner with low polar solvents. Zeolite with increased selectivity favors the desired products trans-10, cis-12 CLA and the cancer inhibitor cis-9, trans- 11 was obtained by the use of ruthenium on $\mathrm{Al}_{2} \mathrm{O}_{3}$ or ruthenium on carbon catalysts $[63,67]$.

Andreas et al. [64] isomerizes technical grade of $55 \%$ linoleic acid to c9, t11-CLA and t10, c-12-CLA isomers in batch wise order at $165^{\circ} \mathrm{C}$ over two series of supported metal catalysts (hydrogen reactivated and non-reactivated). Activated carbon and aluminum oxide, supported Ru, Pd, Os, Ir and Pt-Rh catalysts with $5 \%$ metal loading was screened. In metal catalyst $\mathrm{Ru} /$ Al203, chemisorbed hydrogen increased the isomeriation rate for both the diluted and non-diluted systems. Overall ruthenium catalyst has shown higher selectivity than other metal catalysts.

Gangidi \& Proctor [68] initiated the synthesis of CLA isomers using photoisomerization method. In this method linoleic acid methyl ester (5-10\%) were dissolved in petroleum ether, benzene or carbon disulfide and then exposed to strong light source in presence of iodine as a sensitizer which gives a yield of $80 \%$ of CLA isomers. Jain \& Proctor [69] designed a customized photochemical reaction system for CLA synthesis. The 144 hours of irradiation was initiated by transferring soybean oil to the reaction vessel using iodine as catalyst. A total CLA yield of $24 \%$ $(\mathrm{w} / \mathrm{w})$ total oil was obtained with $15 \%(\mathrm{w} / \mathrm{w})$ iodine and transtrans isomers $(17.5 \%)$ and $c 9, \mathrm{t} 11$ and $\mathrm{t} 10, \mathrm{c} 12$ CLA isomers $(3.5 \%)$ is formed. Later they synthesized higher amount of CLA (75\%) from soya oil which mainly composed of t8, t10-CLA, t9, t11-CLA and t10, t12-CLA [70].
Linoleic acid rich vegetable oils like flax seed oil, soybean oil, sunflower oil and safflower oil were used for the production of conjugated linoleic acid by photo catalytic isomeriation system. Nearly, 700g of deaerated oil sample from all oil samples was transferred to the reaction vessel using $0.15 \%$ iodine as catalyst. A 168 hours of irradiation was conducted, $10 \mathrm{ml}$ of samples were collected every 24 hours of the irradiation for fatty acid analysis. Oils with highest linoleic acid produced more CLA in the order safflower oil > soya oil > corn > flax, sunflower oil does not produced any CLA even though it containing initial levels of LA [71].

Synthesis of conjugated linoleic acids over $\mathrm{Ru}$ supported on different zeolite varying in topology (ZSM-5, BETA, Y) Si/Al ratio and counter caption $(\mathrm{H}+, \mathrm{Na}+\mathrm{Cs}+)$. Combination of $\mathrm{Ru} / \mathrm{Cs}-$ USY with $\mathrm{Si} / \mathrm{Al}$ ratio of 40 identified as most active and selective catalyst for effective isomeriation of methyl linoleate to CLA at $165^{\circ} \mathrm{C}$, produced $0.7 \mathrm{~g}$ of CLA/liter of solvent/ minute [72]. Silva Ramirez et al. [73] synthesized c9, t11 and t10, c12 CLA isomers by microwave irradiation. The experiment was conducted with different set of variables like solvent/LA mass ratio (1:1-6:1), catalyst/LA mass ratio (0.25:1-0.6:1), temperature (160-180 $\left.{ }^{\circ} \mathrm{C}\right)$, catalyst type $(\mathrm{KOH}$ or $\mathrm{NaOH})$ and reaction time. The best optimum conditions for synthesizing CLA isomers (91.21\% equimolar ratio) was $\mathrm{NaOH}$ at a catalyst/LA mass ratio of 0.5:1 and solvent/LA mass ratio of $1: 1$ at $160{ }^{\circ} \mathrm{C}$ during $4 \mathrm{~min}$.

\section{Conclusion}

Conjugated linoleic acid is a mixture of positional and geometric isomers of linoleic acid with two conjugated double bonds at various carbon positions in the fatty acid chain. C-9, $\mathrm{t}-11$ is the most prevalent isomer compromising $80-90 \%$ of the total CLA in food products from ruminants. CLA can be synthesized in tissues endogenously by $\Delta 9$-desaturase enzyme and as intermediate by partial biohydrogenation of unsaturated fatty acids present in the dietary source of rumens [74-76]. Many microbial strains mostly Lactobacillus spp and Butyrivibrio spp were employed for CLA synthesis. Increasing market demand and GRAS status for CLA in 2008 by FDA, researchers and scientists has focused their interest on bulk production of CLA using many metal catalysts and by photo-isomeric methods. It is highly appreciated that, research on CLA synthesis should focus in discovering more number of other bacterial strains and many environmental friendly heterogeneous catalysts with increased yield of specific CLA isomers.

\section{References}

1. Christie WW (2003) Analysis of conjugated linoleic acid-an overview. In: Sebediol JL, Christie WW, Adlof RO (Eds.), Advances in Conjugated Linoleic Acid Research, pp. 1-12.

2. EFSA (European Food Safety Authority) (2010) Scientific opinion on dietary reference values for fats, including saturated fatty acids, polyunsaturated fatty acids, monounsaturated fatty acids, trans fatty acids and cholesterol. The EFSA Journal 8(3): 1461. 
3. Allen CF, Good P (1965) Plant lipids. J Am Oil Chem Soc 42: 610-614.

4. Salton MR (1971) Bacterial membranes. Crit Rev Microbiol 1(1): 161197.

5. Gilbert LI, Chino H (1974) Transport of lipids in insects. J Lipid Res 15(5): 439-456

6. Goodridge AG (1991) Fatty acid synthesis in eukaryotes. In: Dennis EV, Jean EV (Eds.), New Comprehensive Biochemistry, Chap-4, Elsevier, Amsterdam, Netherlands, pp. 111-139.

7. Pariza MW, Hargraves WA (1985) A beef-derived mutagenesis modulator inhibits initiation of mouse epidermal tumors by 7 , 12-dimethylbenz[a]anthracene. Carcinogenesis 8: 1881-1887.

8. Ha YL, Storkson JM, Pariza MW (1990) Inhibition of benzo(a)pyreneinduced mouse fore-stomach neoplasia by conjugated dienoic derivatives of linoleic acid. Cancer Res 50(4): 1097-1101.

9. Viladomiu M, Hontecillas R, Bassaganya-Reira J (2016) Modulation of inflammation and immunity by dietary conjugated linoleic acid. Eur J Pharmacology 785: 87-95.

10. Dilzer A, Park Y (2012) Implication of conjugated linoleic acid (CLA) in human health. Crit Rev Food Sci Nutr 52(6): 488-513.

11. Yang BO, Chen H, Stanton C, Ross RP, Zhang H, et al. (2015) Review of the roles of conjugated linoleic acid in health and disease. Journal Func Foods 15: 314-325.

12. Moon HS (2014) Biological effects of conjugated linoleic acid on obesity-related cancers. Chemico-Biological Interactions 224(5): 189195

13. Lehen TE, Silva MRd, Camacho A, Marcadenti A, Lehen AM, et al. (2015) A review on effects of conjugated linoleic fatty acid (CLA) upon body composition and energetic metabolism. J Int Soc Sports Nutr 12(36): 1-11.

14. Bhattacharya A, Banu J, Rahman M, Causey J, Fernandez G, et al. (2006) Biological effects of conjugated linoleic acids in health and diseases. J Nutri Biochem 17(12): 789-810.

15. Wahle KW, Heys SD, Rotondo D (2004) Conjugated linoleic acids: Are they beneficial or detrimental to health? Prog Lipid Res 43(6): 553587.

16. MacDonald HB (2000) Conjugated linoleic acid and disease prevention: a review of current knowledge. J Am Coll Nutr 19(2): 111-118.

17. Lin H, Boylston TD, Chang MJ (1995) Survey of the conjugated linoleic acid contents of dairy products. J Dairy Sci 78(11): 2358-2365.

18. Koba K, Yanagita T (2014) Health benefits of conjugated linoleic acid (CLA). Obes Res Clin Prac 8(6): 525-532.

19. Ma DW, Wierzbicki AA, Field CJ, Clandinin MT (1999) Conjugated linoleic acid in Canadian dairy and beef products. J Agric Food Chem 47(5): 1956-1960.

20. Fritsche J, Teter B, Sehat N, Roach JAG, Mossoba MM, et al. (1999) Determination of CLA isomers in human milk. Inform 10: 5S1

21. Parodi PW (1997) Conjugated octadecadienoic acids of milk fat. J Dairy Science 60(10): 1550-1553.

22. Chin SF, Liu W, Storkson JM, Ha YL, Pariza MW, et al. (1992) Dietary sources of conjugated dienoic isomers of linoleic acid, a newly recognized class of anticarcinogens. J Food Compos Anal 5(3): 185197.

23. Fritsche J, Steinhardt H (1998) Amounts of conjugated linoleic acid (CLA) in German foods and evaluation of daily intake. Food Research and Technology 206(2): 77-82.

24. Engelke CF, Siebert BD, Gregg K, Wright ADG, Vercoe PE, et al. (2004) Kangaroo adipose tissue has higher concentrations of cis 9, trans 11-conjugated linoleic acid than lamb adipose tissue. Journal of Animal and Feed Sciences 13(1): 689-692.

25. Sieber R, Collomb M, Aeschlimann A, Jelen P, Eyer H, et al. (2004) Impact of microbial cultures on conjugated linoleic acid in dairy products-a review. Int Dairy Journal 14(1): 1-15.

26. KellyML, Berry JR, Dwyer DA, Griinari JM, Chouinard PY, et al. (1998) Dietary fatty acid sources affect conjugated linoleic acid concentrations in milk from lactating dairy cows. Journal of Nutrition 128: 881-885.

27. McGuire MA, McGuire MK, McGuire MS, Grinarri JM (1997) Bovine acid: The natural CLA, In: Cornell Nutrition Conference Feed Manufacturers 59: 217-226.

28. Griinari JM, Bauman DE (1999) Biosynthesis of conjugated linoleic acid and its incorporation into meat and milk in ruminants. In: Yurawecz MP, Mossoba MM, Kramer JKG, Pariza MW, Nelson G (Eds.), Advances in conjugated linoleic acid research Champaign, IL: American Oil Chemists Society Press, USA, pp. 180-200.

29. Harfoot CG (1978) Lipid metabolism in the rumen. Prog Lipid Res $17(1): 21-54$.

30. Dawson RMC, Hemington N, Hazelwood GP (1977) On the role of higher plant and microbial lipases in the ruminal hydrolysis of grass lipids. Br J Nur 38(2): 225-232.

31. Harfoot CG, Hazelwood GP (1988) Lipid metabolism in the rumen. In: Hobson PN (Ed.), The rumen microbial ecosystem. Elsevier Science Publishers. London, pp. 285-322.

32. Bean TM, Jenkins TC, Moate PJ, Kohn RA, Palmqeuist DL, et al. (2000) Effects of amount and source of fat on the rats of lipolysis and biohydrogenation of fatty acids in ruminal contents. J Dairy Sciences 83(11): 2564-2573.

33. Van Nevel CJ, Demeyer DI (1996) Influence of $\mathrm{pH}$ on lipolysis and biohydrogenation of soybean oil by rumen contents in vitro. Reprod Nutr Dev 36(1): 53-63.

34. Kepler CR, Hirons KP, McNeill JJ, Tove SB (1966) Intermediates and products of the biohydrogenation of linoleic acid by Butyrivibrio fibrisolvens. Journal of Biological Chemistry 241: 1350-1354.

35. Bessa RJB, Santos-Silva J, Ribeiro JMR, Portugal AV (2000) Reticulorumen biohydrogenation and the enrichment of ruminant edible products with linoleic acid conjugated isomers. Livestock Production Science 63(3): 201-211.

36. Van Soest PJ (1994) Nutritional ecology of the ruminant. ( $2^{\text {nd }}$ edn), New York, USA.

37. Bauman DE, Baumgard LH, Corl BA, Griinari JM (2005) Biosynthesis of conjugated linoleic acid in ruminants. In Proceedings of the American Society of Animal Science 1999.

38. Corl BA, Baumgard LH, Dwyer DA, Griinari JM, Phillips BS, et al. (2001) The role of $\Delta^{9}$-desaturase in the production of cis-9, trans-11 CLA. Journal of Nutritional Biochemistry 12(11): 622-630.

39. Griinari JM, Corl BA, Lacy SH, Chouinard PY, Nurmela KVV, et al. (2000) Conjugated linoleic acid is synthesized endogenously in lactating dairy cows by $\Delta^{9}$-desaturase. Journal of Nutrition 130(9): 2285-2291.

40. Knight TW, Knowles S, Death AF (2003) Factors affecting the variation in fatty acid concentrations in lean beef from grass-fed cattle in New Zealand and the implications for human health. New Zealand J Agricultural Research 46(2): 83-95.

41. Salminen I, Mutanen M, Jauhiainen M, Aro A (1998) Dietary trans fatty acids increase conjugated linoleic acid levels in human serum. Journal of Nutritional Biochemistry 9(2): 93-98.

42. Gla"ser KR, Scheeder MRL, Wenk C (2000) Dietary C18:1 trans fatty acids increase conjugated linoleic acid in adipose tissue of pigs. European Journal of Lipid Science and Technology 102(11): 684-686. 
43. Loor JJ, Lin XB, Herbein JH (2002) Dietary trans-vaccenic acid (trans11-18:1) increases concentration of cis9, trans11-conjugated linoleic acid (rumenic acid) in tissues of lactating mice and suckling pups. Reprod Nutr Dev 42(2): 85-99.

44. Santora JE, Palmquist DL, Roehrig KL (2000) Trans-vaccenic acid is desaturated to conjugated linoleic acid in mice. Journal of Nutrition 130(2): 208-215.

45. Turpeinen AM, Mutanen M, Aro A, Salminen I, Basu S, et al. (2002) Bioconversion of vaccenic acid to conjugated linoleic acid in humans. American J Clinical Nutrition 76(3): 504-510.

46. Adlof RO, Duval S, Emken EA (2000) Biosynthesis of conjugated linoleic acid in humans. Lipids 35(2): 131-135.

47. Kraft J, Jahreis G (2001) Conjugated linoleic acids: formation and metabolic effects. Erna"hrungs-Umschau 48: 348.

48. Lin TY, Hung TH, Cheng JS (2005) Conjugated linoleic acid production by immobilized cells of Lactobacillus delbrueckii ssp, bulgaricus and Lactobacillus acidophilus. Food Chemistry 92(1): 23-28.

49. Marjatta V, Pekka L, Soili S, Simo L (2004) Enrichment of Conjugated Linoleic Acid in Oats (Avena sativa L.) by Microbial Isomerization. J Agri Food Chem 52(6): 1749-1752.

50. Kishino S, Ogawa J, Ando A, Omura Y, Shimizu S, et al. (2002) Ricinoleic acid and castor oil as substrates for conjugated linoleic acid production by washed cells of Lactobacillus plantarum. Biosci Biotechnol Biochem 66(10): 2283-2286.

51. Kim YJ, Liu RH, Bond DR, Russell JB (2000) Effect of linoleic acid concentration on conjugated linoleic acid production by Butyrivibrio fibrisolvens A38. Applied and Environmental Microbiology 66(12): 5226-5230.

52. Dong M, Qi S (2006) Conjugated Linoleic Acid production by fermentation. International Journal of Food Engineering 2(4).

53. Haifeng Wu (2001) Production, purification and characterization of a conjugated linoleic acid forming enzyme from Lactobacillus acidophilus. Canada.

54. Nunez MR (2005) Production of conjugated linoleic acid by Lactobacillus reuteri 55739, pp. 1-68.

55. Christie WW, Dobson G, Gunstone FD (1997) Isomers in commercial samples of conjugated linoleic acid. Lipids 32(11): 1231.

56. raweez MP, Roach JAG, Mossoba MM, Kramer JKG, et al. (1999) Silverion high-performance liquid chromatographic separation and identification of conjugated linoleic acid isomers. Lipids 33(2): 217221.

57. Park Y, Albright KJ, Liu W, Storkson JM, Cook ME, et al. (1997) Effect of conjugated linoleic acid on body composition in mice. Lipids 32(8): 853-858.

58. Iwata T, Kamegai T, Sato Y, Watanabe K, Kasai M, et al. (1998) Methods for producing Conjugated linoleic acid.

59. Frankel E (1970) Conversion of polyunsaturates in vegetable oils to cis monounsaturates by homogeneous hydrogenation catalysed with chromium carbonyls. J Am Oil Chem Soc 47(1): 11-14.
60. Deshpande VM, Gadkari RG, Mukesh D, Narasimhan CS (1985) Studies on kinetics of catalytic isomerisation of methyl linoleate. J Am Oil Chem Soc 62(4): 734-738.

61. Mukesh D, Narasimhan S, Gadkari R, Deshpande VM (1985) Kinetics of mathematical modelling of isomerisation of methyl linoleate, Pt.I; Isomerisation and hydrogenation. Ind Eng Chem Prod Res Dev 24: 318.

62. Mukesh D, Narasimhan S, Deshpande VM, Ramnarayan K (1988) Isomerization of methyl linoleate on supported ruthenium-nickel catalyst. Ind Eng Chem Res 27: 409.

63. Andreas B, Narendra K, Paivi MA, Natalya VK, Bjarne H, et al. (2003) Isomerization of linoleic acid over supported metal catalysts. Applied Catalysis A: General 245(2): 257-275.

64. Pines H (1981) The chemistry of catalytic hydrocarbon conversions. Academic Press.

65. Krompiec, Stanislaw, Suwinski, Jerzy, Majewski, et al. (1997) Isomerization of vegetable oils catalyzed by horotris (triphenylphosphine) ruthenium(II). Polish Journal of Applied Chemistry 41(1-2): 35-45.

66. Larock RC, Dong X, Chung S, Reddy CK, Ehlers LE, et al. (2001) Preparation of conjugated soybean oil and other natural oils and fatty acids by homogeneous transition metal catalysis. J Am Oil Chem Soc 78(5): 447-453.

67. Andreas B, Narendra K, Paivi MA, Bjarne H, Tapio S, et al. (2004) Heterogeneous catalytic production of conjugated linoleic acid. Org Proc Res Dev 8(3): 341-352.

68. Gangidi RR, Proctor A (2004) Photochemical Production of Conjugated linoleic Acid from Soybean Oil. J of Lipids 39(6): 577-582.

69. Jain VP, Proctor A (2006) Photocatalytic production and processing of conjugated linoleic acid-rich soy oil. J Agric Food Chem 54(15): 55905596.

70. Jain VP, Proctor A (2007) Kinetics of photo irradiation induced synthesis of soya oil-conjugated linoleic acid isomers. J Agric Food Chem 55(3): 889-894.

71. Whitney GA (2009) comparative study of high linoleic acid vegetable oils for the production of conjugated linoleic acid. Inquiry 10, pp. 1-9.

72. An P, Steven G, Walter V, Moniek T, Stuart T, et al. (2011) Design of $\mathrm{Ru}$-zeolites for hydrogen-free production of conjugated linoleic acids. Chem Sus Chem 4(6): 757-767.

73. Silva-Ramirez AS, Rocha-Uribe A, Gonazalez-Chavez MM, Gonazalez C (2017) Synthesis of conjugated linoleic acid by microwave-assisted alkali isomerization using propylene glycol as solvent. Eur Journal Lipid Sci Tech 119(4).

74. Hennessy AA, Ross PR, Fitzgerald GF, Stanton C (2016) Sources and bioactive properties of conjugated dietary fatty acids. Lipids 51(4): 377-397.

75. Park Y (2009) Conjugated linoleic acid (CLA): Good or bad trans fat? J Food Composition and Analysis 22: S4-S12.

76. (2002) US Patent 6,479,683. Process for conjugating fatty acid ester. 


\section{Your next submission with Juniper Publishers} will reach you the below assets

- Quality Editorial service

- Swift Peer Review

- Reprints availability

- E-prints Service

- Manuscript Podcast for convenient understanding

- Global attainment for your research

- Manuscript accessibility in different formats ( Pdf, E-pub, Full Text, Audio)

- Unceasing customer service

Track the below URL for one-step submission https://juniperpublishers.com/online-submission.php 